\title{
Fluticasone propionate induced alterations to lung function and the immunopathology of asthma over time
}

\author{
John L Faul, Colm T Leonard, Conor M Burke, Vincent J Tormey, Leonard W Poulter
}

\begin{abstract}
Background-Inhaled corticosteroids are the most widely used treatment for asthma, a disease characterised by both functional and immunopathological abnormalities. This study investigated the relative effects of inhaled corticosteroids on these two features of asthma over time. Methods-A randomised, double blind, placebo controlled, parallel group study with inhaled fluticasone propionate, (FP $2 \mathrm{mg}$ daily) was conducted in 27 patients with asthma. Following baseline analysis, the study tested the effects of short term (two weeks) and longer term (eight weeks) treatment. At each time point $(0,2$, and 8 weeks) lung function tests were performed and endobronchial biopsy specimens obtained to determine the distribution and number of lymphocyte, macrophage and eosinophil subsets using immunohistological analysis. Twenty three patients completed the study, 11 on FP and 12 placebo.
\end{abstract}

Results- $\mathrm{FEV}_{1}, \Delta \mathrm{FEV}_{1}, \mathrm{FEF}_{25-75}$, and $\mathrm{FEV}_{1} I$ FVC all improved after two weeks of FP treatment. This improvement was maintained but not increased after eight weeks. $P_{20} F_{E V}$ showed a trend to increase but was not significantly improved at eight weeks. No significant changes were seen in the placebo group. The numbers of $T$ cells, macrophages, and eosinophils in the bronchial wall were reduced by two weeks of treatment with FP but were unaltered by placebo. The improvement offered by FP continued over the eight week period. Reductions in CD4:CD8 ratio and numbers of activated (EG2+) eosinophils were only significant after eight weeks of treatment.

Conclusions-These results reveal that FP influences both functional and immunopathological parameters of asthma. Temporal relationships suggest that these are parallel but not necessarily interrelated effects. While short term treatment is effective in "normalising" the functional abnormalities in asthma, the impact of FP on bronchial inflammation appears to be progressive, taking up to eight weeks and more.

(Thorax 1998;53:753-761)

Keywords: asthma; steroids; physiology; immunopathology; kinetics
Asthma is recognised as a chronic inflammatory disease of the airway characterised by infiltration of the bronchial wall by activated $T$ lymphocytes and eosinophils. ${ }^{1-3}$ Inhaled corticosteroids represent an important treatment and early intervention is currently recommended. ${ }^{4-6}$ Previous biopsy studies of the anti-inflammatory effects of different corticosteroids on the bronchial mucosa in asthmatic subjects at various time points have shown a reduction in the number of mast cells, eosinophils, lymphocytes, and macrophages after four weeks, ${ }^{7}$ six weeks, ${ }^{8}$ three months, ${ }^{9}$ and up to 10 years of corticosteroid therapy. ${ }^{10}$

Asthma is defined clinically in terms of abnormal airway function. ${ }^{11}{ }^{12}$ Asthmatic subjects usually demonstrate variable airflow obstruction and bronchial hyperresponsiveness, either spontaneously or when challenged with inhaled histamine, methacholine or cold air. ${ }^{13}$ Some studies reveal relationships between immunopathological parameters and airway hyperresponsiveness. ${ }^{14-18}$ These two variables may, however, develop independently. ${ }^{10}{ }^{19}$ It is thought, but remains unproven, that the coincidence of airways hyperresponsiveness and airway inflammation is seen in virtually all asthmatics and that the two are interrelated.

Although treatment guidelines strongly recommend the early use of corticosteroids in asthma, ${ }^{42} 2021$ their precise mode of action is unknown. It remains unclear which specific components of the inflammatory reaction are the first to be affected by inhaled corticosteroids, which are preferentially downregulated, and which are the most sensitive to respond to steroid therapy. Furthermore, although it is also well established that corticosteroids lead to improved airflow in asthma, it remains unclear how this effect is related to alterations in immunopathology. No study to date has compared the acute and longer term effects of inhaled corticosteroid therapy on the bronchial mucosa. Furthermore, no controlled study has tested functional and immunohistological effects of inhaled corticosteroids at three successive time points within the same study population.

Fluticasone propionate (FP) is a new inhaled corticosteroid with high topical activity and low systemic bioavailability. ${ }^{22}$ It is considered the most potent of the inhaled corticosteroids currently available for treatment of this disease ${ }^{4}$ and controlled studies have shown it to be a well tolerated and effective therapy. ${ }^{24-26}$ It is clearly important to establish not only which parameters of immunological and physiologi- 
Table 1 Characteristics of the 23 patients who completed the study protocol

\begin{tabular}{lllllll}
\hline Age (years) & Sex & Asthma duration & Atopy & FEV $(\%$ pred $)$ & AFEV $(\%)$ & Therapy \\
\hline 21 & $\mathrm{~F}$ & 1 year & ++ & $2.95(95)$ & 18 & $\mathrm{FP}$ \\
31 & $\mathrm{~F}$ & $>10$ years & ++ & $1.69(52)$ & 24 & $\mathrm{FP}$ \\
42 & $\mathrm{~F}$ & 1 year & - & $2.02(82)$ & 16 & $\mathrm{FP}$ \\
28 & $\mathrm{~F}$ & $>10$ years & ++ & $1.94(60)$ & 50 & $\mathrm{FP}$ \\
19 & $\mathrm{M}$ & $>10$ years & +++ & $2.56(54)$ & 80 & $\mathrm{FP}$ \\
25 & $\mathrm{M}$ & 1 year & ++ & $4.86(108)$ & 12 & $\mathrm{FP}$ \\
27 & $\mathrm{M}$ & $>10$ years & ++ & $1.88(46)$ & 62 & $\mathrm{FP}$ \\
23 & $\mathrm{~F}$ & 6-10 years & +++ & $2.55(85)$ & 18 & $\mathrm{FP}$ \\
23 & $\mathrm{M}$ & $>10$ years & +++ & $2.49(56)$ & 44 & $\mathrm{FP}$ \\
28 & $\mathrm{M}$ & 1 year & - & $4.11(95)$ & 19 & $\mathrm{FP}$ \\
45 & $\mathrm{M}$ & $>10$ years & +++ & $2.05(95)$ & 71 & $\mathrm{FP}$ \\
21 & $\mathrm{M}$ & $>10$ years & ++ & $3.41(79)$ & 22 & $\mathrm{P}$ \\
33 & $\mathrm{M}$ & $>10$ years & ++ & $1.88(49)$ & 26 & $\mathrm{P}$ \\
24 & $\mathrm{~F}$ & $>10$ years & +++ & $2.22(72)$ & 33 & $\mathrm{P}$ \\
24 & $\mathrm{M}$ & $>10$ years & - & $3.65(84)$ & 7 & $\mathrm{P}$ \\
40 & $\mathrm{M}$ & $>10$ years & +++ & $1.98(50)$ & 76 & $\mathrm{P}$ \\
36 & $\mathrm{M}$ & $>10$ years & +++ & $1.77(40)$ & 64 & $\mathrm{P}$ \\
36 & $\mathrm{~F}$ & 1-5 years & ++ & $2.84(88)$ & 13 & $\mathrm{P}$ \\
28 & $\mathrm{M}$ & $>10$ years & ++ & $2.67(59)$ & 30 & $\mathrm{P}$ \\
22 & $\mathrm{M}$ & 1 year & - & $3.94(94)$ & 8 & $\mathrm{P}$ \\
34 & $\mathrm{M}$ & 1 year & ++++ & $3.25(74)$ & 11 & $\mathrm{P}$ \\
35 & $\mathrm{M}$ & 1 year & - & $4.26(100)$ & 5 & $\mathrm{P}$ \\
20 & $\mathrm{M}$ & $>10$ years & ++++ & $2.64(66)$ & 27 & $\mathrm{P}$ \\
\hline $\mathrm{FP}$ & & & & & & \\
\hline
\end{tabular}

$\mathrm{FP}=$ fluticasone propionate $\mathrm{P}=$ placebo.

cal dysfunction are affected by inhaled therapy, but also the temporal relationship one to the other as, in this way, both dose and regimen of inhaled corticosteroids might be best tailored to the specific immunopathological and lung function status of the patient. In the present study high dose inhaled fluticasone propionate ( $2 \mathrm{mg}$ /day) was administered to asthmatic subjects in order to give the most potent anti-asthmatic activity.

To determine the temporal relationships between functional and immunopathological parameters, a randomised, double blind, placebo controlled study of high dose inhaled FP was performed in patients with mild to moderate asthma. Functional and immunological parameters were measured at baseline and then at two subsequent time points (two and eight weeks) to investigate both short and long term effects of treatment. At each time point fibreoptic bronchoscopy with endobronchial biopsy was performed to investigate changes to specific subpopulations of inflammatory cells within the bronchial mucosa, reflecting the effect of treatment on immunopathological indices. ${ }^{27}{ }^{28}$ The temporal relationships between corticosteroid induced changes to functional and immunological parameters are presented.

\section{Methods}

SUBJECTS

Twenty seven asthmatic subjects (ATS criteria for asthma ${ }^{11}$ ) were recruited. None had suffered an exacerbation of asthma or taken corticosteroid therapy within the three months before the study. Baseline forced expiratory volume in one second $\left(\mathrm{FEV}_{1}\right)$ for all subjects was $>40 \%$ predicted and all subjects showed an increase in $\mathrm{FEV}_{1}$ of more than $250 \mathrm{ml}$ and more than $12.5 \%$ increase after inhaled salbutamol. All subjects demonstrated bronchial reactivity as documented by a histamine $\mathrm{PC}_{20} \mathrm{FEV}_{1}$ of $<8 \mathrm{mg} / \mathrm{ml}$ within four weeks of entry.

Subjects were excluded if they were pregnant or lactating, had a psychiatric illness, or other concurrent clinical condition. During the study no supplementary oral or inhaled corticosteroids were allowed. Rescue inhalers were confined to salbutamol by metered dose inhaler.

The study protocol was approved by the ethics committee at the James Connolly Memorial Hospital, Dublin and by the National Drugs Advisory Board of Ireland. Full written informed consent was obtained from each patient. The nature of the study demanded great care to be taken to provide an easily accessible and prompt medical backup for the subjects enrolled. A team of senior clinicians was on call 24 hours a day, seven days a week to provide continuous medical backup, to arrange unscheduled visits to the hospital, and to ensure early withdrawal from the study of patients in the event of deteriorating asthma or intercurrent illness. Of 27 patients recruited, four were withdrawn from the study, two due to non-compliance with medication (one placebo, one FP) and two due to pregnancy (one placebo, one FP). Details of the 23 subjects who completed the study are shown in table 1.

STUDY DESIGN

This study was conducted as a randomised, double blind, placebo controlled, parallel group trial. It was divided into a baseline period of one week and a treatment period of eight weeks. During the one week run-in period subjects were tested for compliance and inhaler technique by being asked to use a placebo inhaler (four puffs twice daily) and record peak flow measurements and symptom scores twice daily in a diary card. At the end of the baseline period all subjects were randomly assigned to one of two treatment groups receiving either FP (four puffs of $250 \mathrm{mg}$ twice daily) or a matched placebo through a metered dose inhaler attached to an aerosol chamber (Volumatic spacer, Allen \& Hanburys, Greenford, $\mathrm{UK})$.

Subjects attended the laboratory at entry day (day -7 ) and days $-1,0,13,14,55$, and 56 of the study period (day 0 represents the day treatment was started). Bronchodilator medication and caffeine containing drinks were withheld for at least 12 hours before each study visit and subjects always attended the laboratory at 09.00 hours. Subjects underwent complete physical examination and routine haematological, urine analysis, and biochemical tests at the screening visit (day -7 ) and on days 0 , 14, and 56. At each visit compliance with medication and adverse effects were checked and recorded. Forced vital capacity (FVC) and $\mathrm{FEV}_{1}, \Delta \mathrm{FEV}_{1}$ after bronchodilator, $\mathrm{FEV}_{1} / \mathrm{FVC}$ and $\mathrm{FEF}_{25-75}$ were recorded at each visit using a computerised spirometer (Gould 2400). At entry day and days $0-1,13$, and 55 (at the same time of day in each case) histamine bronchial provocation challenges were performed according to a standardised technique. ${ }^{29} \mathrm{~A}$ complete dose-response curve for inhaled histamine was recorded using doubling concentrations starting at $0.03 \mathrm{mg}$ up to $16 \mathrm{mg} / \mathrm{ml}$ of histamine dissolved in normal saline. During histamine challenges $\mathrm{FEV}_{1}$ was measured 30 
and 90 seconds after each dose. The test was terminated if $\mathrm{FEV}_{1}$ decreased by more than $20 \%$ from the post-saline value or if a concentration of $16 \mathrm{mg} / \mathrm{ml}$ was reached. $\mathrm{PC}_{20}$ was determined by linear interpolation of the concentration $\mathrm{FEV}_{1}$ response curve. Patients were allowed neither salbutamol nor salmeterol for 12 and 36 hours, respectively, prior to bronchial challenge.

Allergy tests were performed at the screening visit (day 0-7). Patients were considered atopic if they gave a history of bronchospasm after allergen exposure and exhibited a positive skin prick test to at least one of a panel of common allergens (house dust mite, grass, pollen, cat, dog, birch, pollen).

Bronchodilator responses were studied four hours prior to bronchoscopy on days 0,14 and 56. $\mathrm{FEV}_{1}$ was measured before and 20 minutes after salbutamol $200 \mathrm{mg}$ administered via a Volumatic spacer device. The post bronchodilator $\mathrm{FEV}_{1}$ and percentage change from baseline were recorded. In all cases spirometric values were also recorded as percentage predicted.

FIBREOPTIC BRONCHOSCOPY

Fibreoptic bronchoscopy was performed at three time points (days 0, 14 and 56) using a flexible fibreoptic bronchoscope (Olympus $\mathrm{BF} 10)$. Subjects were sedated with intravenous propofol (Power) and continuous oxygen was given and oxygen saturation and ECG monitored throughout the procedure. Up to three endobronchial biopsy specimens were taken through the bronchoscope with spiked cup forceps from the second generation right upper lobe bronchus. The biopsy specimens were immediately placed on sterile PBS moistened gauze, embedded in OCT medium and snap frozen in melting isopentane previously cooled in liquid nitrogen. The samples were stored in liquid nitrogen until further analysis.

\section{IMMUNOPATHOLOGICAL INVESTIGATIONS}

Cryostat sections ( $6 \mu \mathrm{m}$ thick) of the endobronchial biopsy specimens were cut at $-25^{\circ} \mathrm{C}$, air dried for 60 minutes, fixed in chloroform/ acetone (1:1), wrapped in cling film and stored at $-20^{\circ} \mathrm{C}$ until used. Each biopsy specimen was sectioned within one month of freezing with up to 40 sections being stored. Representative sections of all samples were stained with $0.1 \%$ toluidine blue to reveal morphology and tissue integrity. Immunohistological techniques were employed to identify subsets of immunocompetent cells. For each test on each subject sections from biopsy specimens at each time point were analysed together. Due to the blinded nature of the study it was not possible to analyse groups together and, for logistical reasons, it was not possible to analyse all specimens at particular time points together. However, no sections were stored for more than six weeks.

The indirect immunoperoxidase technique was used to identify $\mathrm{T}$ cells (using a cocktail of monoclonal antibodies CD2, CD3, CD5 and CD8) all produced in the RFHSM, and primed cells were identified using the mono- clonal antibody CD45RO, RFHSM. Macrophage/monocytes were identified using CD68 (Dako, UK), total eosinophils by EG1 (Pharmacia Diagnostics, UK), and activated eosinophils by EG2 (Pharmacia Diagnostics, UK). Double immunofluorescence techniques $^{30}$ were applied to determine CD4:CD8 $\mathrm{T}$ cell ratios and relative proportions of inductive (RFD1+ RFHSM), effector (RFD7+ RFHSM), and suppressive (RFD1+/ RFD7+) macrophages.

QUANTIFICATION OF IMMUNOHISTOLOGY

Numbers of immunocompetent cells were quantified by two investigators with no knowledge of a subject's identity or treatment limb. The distribution and number of immunocompetent cells was assessed using a "Solitaire" computerised image analysis system (Seescan, Cambridge, UK). ${ }^{31}$ Three areas of bronchial wall (epithelium and subepithelial connective tissue to a depth of approx $150 \mu \mathrm{m}$ ) were measured in each section. Total areas of $12 \times 10^{4} \mu \mathrm{m}^{2}$ were quantified on duplicate sections for each cell type in samples for each patient. Areas of each high power field measured were determined with the image analyser by drawing frames around the area to be quantified. These frames were designed to avoid damaged areas and areas of muscle and cartilage. The numbers of positive cells within framed areas were counted and this number was divided by the area of section measured by the computer. ${ }^{32}$ Cell numbers are thus expressed as cells/unit area, the unit area being $10^{4} \mu \mathrm{m}^{2}$.

Immunofluorescence preparations were used to determine CD4:CD8 ratios using a Zeiss fluorescence microscope fitted with epi-illumination and appropriate barrier filters for FITC and TRITC, as previously described in full. ${ }^{30}$ Numbers of CD4+ and CD $8+$ cells were counted in high power fields. Either numbers for the whole section were counted or $\geqslant 100$ cells were observed.

The ratio was recorded as number $\mathrm{CD} 4+$ / number $\mathrm{CD} 8+$. The same approach was used to measure proportions of inductive (D1+), effector $(\mathrm{D} 7+)$, and suppressive $(\mathrm{D} 1+\mathrm{D} 7+)$ macrophages. Numbers of D1+ cells (green fluorescence), D7+ cells (red fluorescence), and D1+ D7+ cells (fluorescent for red and green) were recorded throughout the section. Relative proportions were then calculated by the formula:

$$
\frac{\text { No. of specific subset }}{(\mathrm{D} 1+)+(\mathrm{D} 7+)+(\mathrm{D} 1+\mathrm{D} 7+)} \times 100
$$

\section{STATISTICS}

For all parameters tested the median values for both the FP and placebo groups at baseline and at two and eight weeks were determined and are plotted one against the other to reflect a direct comparison of absolute values for each group.

The relative change after two or eight weeks was expressed as T14/T0 or T56/T0. These fractions were calculated for each subject in 
Table 2 Baseline data (TO) on fluticasone and placebo groups

\begin{tabular}{|c|c|c|c|c|}
\hline \multirow[b]{2}{*}{ Parameter } & \multicolumn{2}{|c|}{ Fluticasone } & \multicolumn{2}{|l|}{ Placebo } \\
\hline & Median & Range & Median & Range \\
\hline $\mathrm{FEV}_{1}$ (litres) & 2.49 & $1.69-4.86$ & 2.69 & $1.77-4.26$ \\
\hline$\Delta \mathrm{FEV}_{1}(\%)$ & 24 & $12-80$ & 22 & $5-76$ \\
\hline $\mathrm{FEV}_{1} / \mathrm{FVC} \%$ & 67 & $43-77$ & 65 & $40-84$ \\
\hline $\mathrm{FEF}_{25-75}$ (litres) & 1.33 & $0.72-3.93$ & 1.91 & $0.62-3.89$ \\
\hline $\mathrm{PC}_{20} \mathrm{FEV}_{1}(\mathrm{mg})$ & 0.19 & $0.03-1.74$ & 0.11 & $0.03-8$ \\
\hline $\mathrm{T}$ cells $\left(\right.$ no. $\left./ 10^{4} \mu \mathrm{m}^{2}\right)$ & 6.3 & $4.1-14.4$ & 5.2 & $3.8-17.3$ \\
\hline Primed T cells $\left(\right.$ no. $\left./ 10^{4} \mu \mathrm{m}^{2}\right)$ & 4.9 & $3.1-12.5$ & 4.3 & $2.7-13.6$ \\
\hline CD4:CD8 ratio & 2.8 & $0.5-5.5$ & 2.15 & $0.7-4.0$ \\
\hline CD68+ cells (no. $/ 10^{4} \mu \mathrm{m}^{2}$ ) & 4.12 & $2.3-11.2$ & 3.7 & $1.9-12.5$ \\
\hline $\mathrm{D} 1+\mathrm{MQ}$ subset $(\%)+$ & 33 & $6-55$ & 35 & $15-46$ \\
\hline $\mathrm{D} 7+\mathrm{MQ}$ subset $(\%)$ & 46 & $23-68$ & 47 & $33-60$ \\
\hline $\mathrm{D} 1+/ \mathrm{D} 7+\mathrm{MQ}$ subset $(\%)$ & 20.5 & $8-33$ & 20.5 & $14-26$ \\
\hline Eosinophils (no. $\left./ 10^{4} \mu \mathrm{m}^{2}\right)$ & 1.7 & $0.5-2.4$ & 1.25 & $0.05-2.2$ \\
\hline Activated eosinophils (no. $/ 10^{4} \mu \mathrm{m}^{2}$ ) & 1.5 & $0.05-1.9$ & 0.45 & $0.05-1.88$ \\
\hline
\end{tabular}

†Percentage of total stained cells showing specific phenotype.

each group. Results were then expressed as median and range within each group at each time point.

In all cases statistical significance was determined using the non-parametric MannWhitney test for non-paired data. Significance was taken at the level of $\mathrm{p} \leqslant 0.05$ using $95 \%$ confidence intervals.

To represent overall FP induced change with time the formula (T14FP/T0FP)-(T14P/ TOP) was used which represented the overall median change after two weeks of treatment. T56 figures were substituted in the same formula to determine the overall effect of FP after eight weeks.

\section{Results}

LUNG FUNCTION

Baseline values (T0) for all lung function data were not significantly different between subjects randomised to the FP and placebo groups (table 2).

The study first compared the effects of FP and placebo over a two week period. After 14 days of treatment an improvement was seen in $\mathrm{FEV}_{1}$ in the FP group which rose significantly compared with the placebo group ( $\mathrm{p}<0.05$, fig 1A). The change after bronchodilation was reduced compared with placebo $(\mathrm{p}<0.02)$ and $\mathrm{FEV}_{1} / \mathrm{FVC} \%$ was raised $(\mathrm{p}<0.02$, figs $1 \mathrm{~B}$ and 1C). An increase in $\mathrm{FEF}_{25-75}$ was also seen (fig 1D), but the absolute values were not significantly different from that of the placebo group as the median baseline data were higher in the placebo group. No change was seen in the $\mathrm{PC}_{20}$ $\mathrm{FEV}_{1}$ in either group (data not shown).

To determine whether the changes occurring in the FP group were significant when compared with the effects of placebo, the relative change for each parameter expressed as the

Table 3 Effect of 14 days of treatment (T14) with fluticasone on physiological parameters $\star$

\begin{tabular}{lllllll}
\hline & \multicolumn{2}{l}{ Fluticasone $(n=11)$} & & \multicolumn{2}{l}{ Placebo $(n=12)$} & \\
\cline { 2 - 3 } & Median & Range & & Median & Range & p valuet \\
\hline $\mathrm{FEV}_{1}$ & 1.2 & $0.93-1.63$ & & 0.965 & $0.77-1.21$ & 0.0056 \\
$\Delta \mathrm{FEV}_{1}$ & 0.47 & $0.16-1.7$ & & 1.16 & $0.45-3.77$ & 0.021 \\
$\mathrm{FEV}_{1} / \mathrm{FVC}$ & 1.15 & $0.95-1.39$ & & 0.98 & $0.75-1.16$ & 0.0089 \\
$\mathrm{FEF}_{25-75}$ & 1.56 & $0.86-2.69$ & & 0.96 & $0.58-1.54$ & 0.0062 \\
$\mathrm{PC}_{20} \mathrm{FEV}_{1}$ & 1.06 & $0.1-4$ & & 0.91 & $0.28-2.72$ & 0.29 \\
\hline
\end{tabular}

*All figures are ratios reflecting T14/T0 data for all parameters.

†Mann-Whitney test for non-parametric data. ratio T14/T0 was calculated for both $\mathrm{FP}$ and placebo groups and these figures were compared using the Mann-Whitney test. This analysis showed that the changes caused by FP treatment for all parameters were significantly different from those in the placebo group (table 3).

After eight weeks a further small rise in $\mathrm{FEV}_{1}$ was seen in the FP group (fig 1A); however, by this time an increase in median $\mathrm{FEV}_{1}$ was also seen in the placebo group to a point where no statistical difference between the groups was demonstrable $(\mathrm{p}>0.05)$. Reversibility and the $\mathrm{FEV}_{1} / \mathrm{FVC} \%$ also showed a further modest rise over the eight week period but fell in the placebo group. A significant difference was recorded for both these parameters between the FP and placebo groups ( $p<0.02$ in both cases; figs $1 \mathrm{~B}$ and $\mathrm{C}) . \mathrm{FEF}_{25-75}$ continued to rise in the FP group over eight weeks (fig 1D) but fell in the placebo group. At eight weeks absolute values for FP treated subjects were significantly higher than those of the placebo group ( $p$ <0.05). No significant difference in $\mathrm{PC}_{20} \mathrm{FEV}_{1}$ was seen even after eight weeks of treatment in either group (data not shown).

To determine whether the changes seen in the FP group were significant compared with the changes in the placebo group, the relative change (0-8 weeks) was calculated for both groups as described in the Methods section. This revealed that all parameters in the FP group with the exception of $\mathrm{PC}_{20} \mathrm{FEV}_{1}$ showed a significant improvement over the placebo group by day 56 (table 4 ). This was true even for the $\mathrm{FEV}_{1}$ data where absolute values were not significantly different when FP and placebo were compared (see above). A comparison of the results in tables 3 and 4 also showed that the effects of FP at day 14 are sustained but not significantly improved up to day 56 .

\section{IMMUNOPATHOLOGY}

At baseline (T0) all patients showed evidence of bronchial inflammation on biopsy section. No significant difference was detected between subjects in the FP group and those treated with placebo (table 2), although considerable variability was seen in some parameters within each group. No significant changes to macrophage subset ratios was detected at either two weeks or eight weeks in either group (data not shown).

After two weeks of treatment reductions in the numbers of $\mathrm{T}$ cells, CD45RO+ $\mathrm{T}$ cells, CD4:CD8 ratios, eosinophils (EG1+) and activated eosinophils (EG2+) were seen (fig 2 $\mathrm{a}-\mathrm{f})$. However, with absolute values a comparison with data from the placebo group showed no significant difference ( $p>0.05$ in each case). The reduction in macrophages (CD68+ cells) brought the numbers of these cells to a level significantly lower than that in the placebo group ( $p<0.05$; fig $2 \mathrm{D}$ ). When the relative changes in the absolute values were compared between the two groups, however, it was found that significant differences in relative change occurred in the FP group in relation to numbers of $\mathrm{T}$ cells, primed $\mathrm{T}$ cells, CD68+ cells, and eosinophils (table 5). 

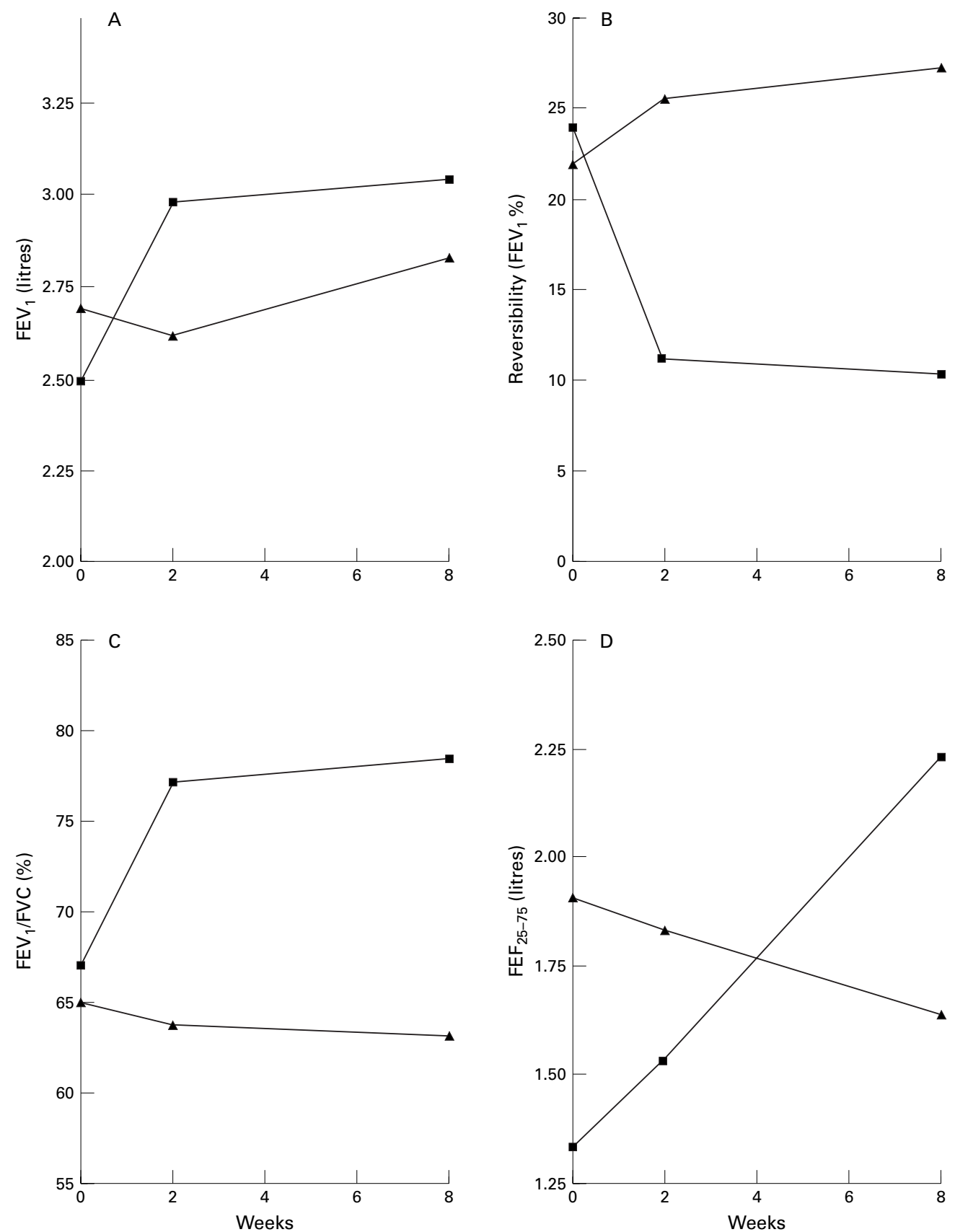

Figure 1 Absolute median values for (A) $F E V_{1}$, (B) reversibility $F E V_{1} \%,(C) F E V_{1} / F V C \%$ and (D) $F E F_{25-75}$ at

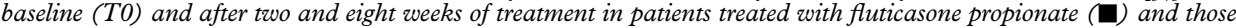
receiving placebo (A).

After eight weeks the absolute values of $\mathrm{T}$ cells, primed $\mathrm{T}$ cells, and eosinophil numbers were significantly different between the FP and placebo groups (fig $2 \mathrm{~A}, \mathrm{~B}, \mathrm{E}$; $\mathrm{p}<0.01,<0.02$, and $<0.05$, respectively). No difference was

Table 4 Effect of 56 days of treatment (T56) on physiological parameters *

\begin{tabular}{lllllll}
\hline & \multicolumn{2}{l}{ Fluticasone $(n=11)$} & & \multicolumn{2}{l}{ Placebo $(n=12)$} & \\
\cline { 2 - 3 } & Median & Range & & Median & Range & p valuet \\
\hline $\mathrm{FEV}_{1}$ & 1.22 & $1.03-1.54$ & & 0.95 & $0.62-1.25$ & 0.007 \\
$\Delta \mathrm{FEV}_{1}$ & 0.436 & $0.11-0.88$ & & 1.24 & $0.27-4.92$ & 0.0028 \\
$\mathrm{FEV}_{1} / \mathrm{FVC}$ & 1.17 & $1.0-1.54$ & & 0.97 & $0.65-1.2$ & 0.0056 \\
$\mathrm{FEF}_{25-75}$ & 1.68 & $1.01-2.42$ & & 0.86 & $0.38-1.65$ & 0.003 \\
$\mathrm{PC}_{20} \mathrm{FEV}_{1}$ & 1.67 & $0.26-8.0$ & & 0.82 & $0.22-2.72$ & 0.09 \\
\hline
\end{tabular}

^All figures are ratios reflecting T56/T0 data for all parameters. †Mann-Whitney test for non-parametric data. recorded in absolute numbers of macrophages and activated eosinophils nor in the CD4:CD8 ratios ( $p>0.05$ in each case; fig $2 \mathrm{C}, \mathrm{D}, \mathrm{F}$ ). However, when the relative changes in the FP and placebo groups were compared over eight weeks significant differences were recorded in the relative reductions in $T$ cells, primed $T$ cells, and activated eosinophils (table 6).

\section{TEMPORAL RELATIONSHIPS}

To reveal the overall effects of FP the median figures of ratios reflecting changes associated with the first two weeks of the study and the overall eight week period were determined by subtracting the median ratios of the placebo groups from those of the FP group. Manipu- 

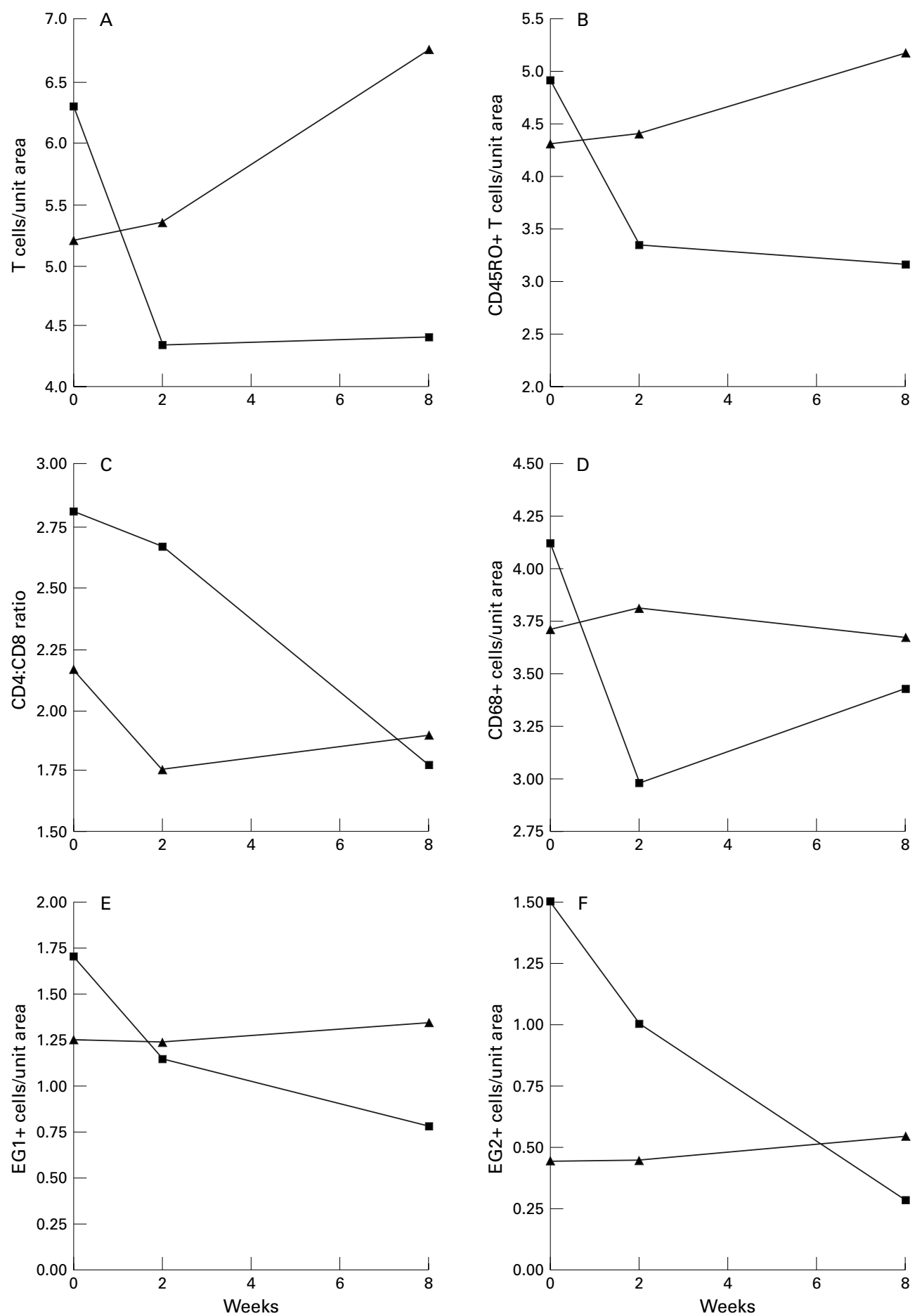

Figure 2 Absolute median values for (A) T cell numbers, (B) CD45RO+ T cell numbers, (C) CD4:CD8 ratio, (D) $C D 68+$ macrophage numbers, $(E)$ EG1 + cells and $(F)$ EG2+ cell numbers. A cell number relative to tissue unit area of

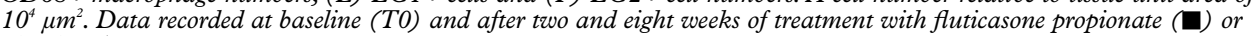
placebo ( $\mathbf{\Lambda})$.

lation of these data left the median ratios, reflecting the overall effect of the FP (see Methods section).

All the FP induced changes to functional status which were statistically significant occurred within the first two weeks of treatment (fig 3A). However, the effects of FP on immunological parameters were variable. $\mathrm{T}$ cell numbers and the numbers of primed $\mathrm{T}$ cells (CD45RO+ve) fell during the first two weeks of treatment (fig 3B). The subsequent

six weeks of treatment caused a further modest fall in $\mathrm{T}$ cell and primed $\mathrm{T}$ cell numbers, and a reduction in the CD4:CD8 ratios was also seen (fig 3B).

Eosinophil numbers were significantly reduced by FP in the first two weeks of treatment and then continued to fall, although less dramatically (fig 3C). "Activated" eosinophils showed a modest fall over the first two weeks but the subsequent treatment period caused the population to drop significantly further. 

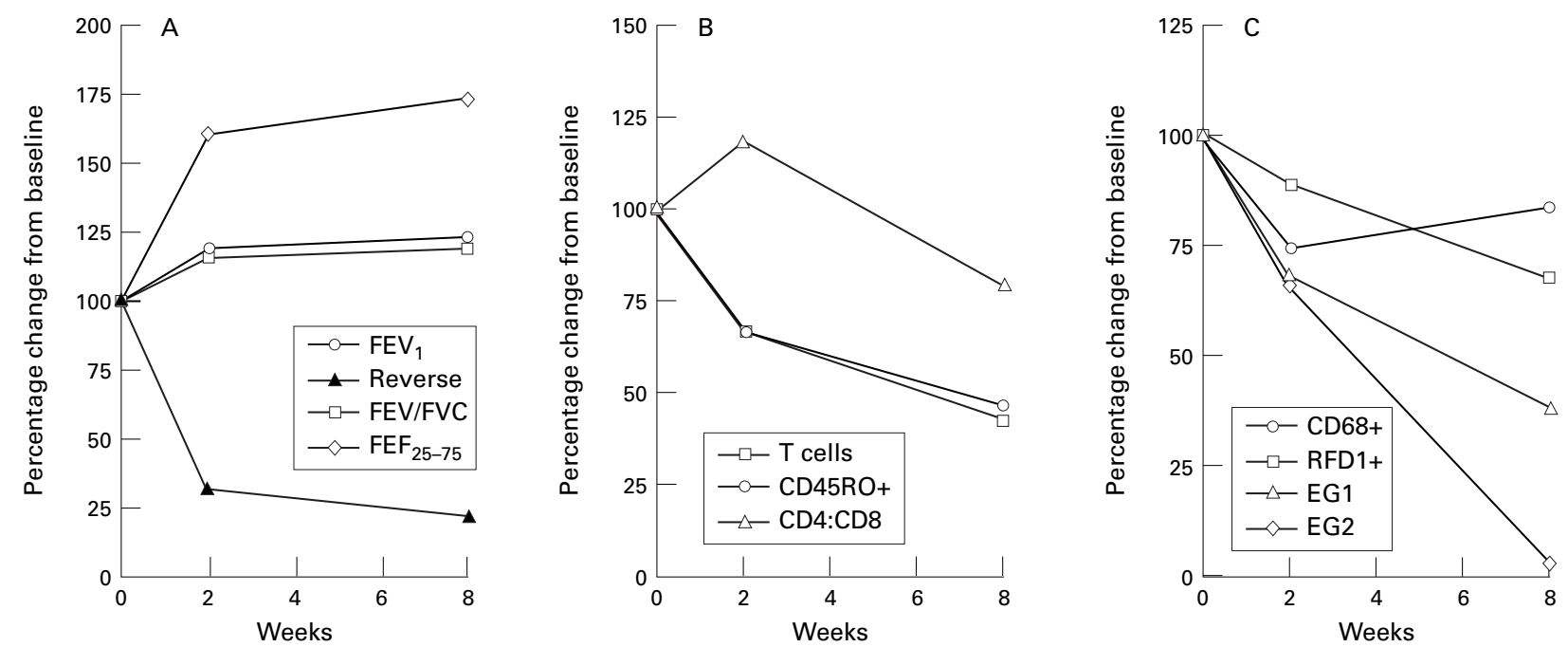

Figure 3 Schematic representation of the overall effects of inhaled fluticasone propionate (FP) on physiological and immunological parameters in the 11 subjects. Each point represents the median percentage change from baseline in the FP group after the median change in the placebo group has been subtracted. All abbreviations as for figs 1 and 2.

Table 5 Effect of 14 days of treatment (T14) on immunological parameters

\begin{tabular}{lllllll}
\hline & \multicolumn{2}{l}{ Fluticasone $(n=11)$} & & \multicolumn{2}{l}{ Placebo $(n=12)$} & \\
\cline { 2 - 3 } & Median & Range & & Median & Range & p value + \\
\hline T cells & 0.69 & $0.41-1.59$ & & 1.03 & $0.68-1.36$ & 0.015 \\
Primed T cells & 0.68 & $0.35-1.7$ & & 1.02 & $0.57-1.3$ & 0.021 \\
CD4:CD8 ratios & 0.95 & $0.22-2.5$ & & 0.81 & $0.25-1.69$ & 0.97 \\
CD68+ cells & 0.72 & $0.45-1.39$ & & 1.03 & $0.32-1.15$ & 0.023 \\
D1+MQ & 0.69 & $0.25-4.6$ & & 0.8 & $0.53-1.4$ & 0.16 \\
D7+MQ & 1.27 & $0.74-2.15$ & & 1.25 & $0.78-1.79$ & 0.91 \\
D1+/D7+MQ & 0.88 & $0.45-2.45$ & & 0.88 & $0.45-1.86$ & 0.77 \\
Eosinophils & 0.67 & $0.03-1.16$ & & 0.98 & $0.02-38$ & 0.045 \\
Activated eosinophils & 0.67 & $0.03-1.78$ & & 1.0 & $0.13-16$ & 0.12 \\
\hline
\end{tabular}

*All figures are ratios reflecting T14/T0 data for each parameter.

†Mann-Whitney test for non-parametric data.

Table 6 Effect of 56 days of treatment (T56) on immunological parameters

\begin{tabular}{lllllll}
\hline & \multicolumn{2}{l}{ Fluticasone $(n=11)$} & & \multicolumn{2}{l}{ Placebo $(n=12)$} & \\
\cline { 2 - 3 } & Median & Range & & Median & Range & p valuet \\
\hline T cells & 0.7 & $0.36-1.04$ & & 1.3 & $0.48-2.1$ & 0.048 \\
Primed T cells & 0.64 & $0.39-1.69$ & & 1.2 & $0.44-2.19$ & 0.015 \\
CD4:CD8 ratios & 0.63 & $0.33-1.36$ & & 0.88 & $0.07-2.31$ & 0.3 \\
CD68+ cells & 0.83 & $0.06-1.27$ & & 0.99 & $0.24-1.68$ & 0.1 \\
D1+MQ & 0.65 & $0.15-4.02$ & & 1.0 & $0.43-1.27$ & 0.49 \\
D7+MQ & 1.01 & $0.71-2.23$ & & 1.06 & $0.73-1.45$ & 0.8 \\
D1+/D7+MQ & 1.17 & $0.58-2.67$ & & 1.25 & $0.36-2.5$ & 0.83 \\
Eosinophils & 0.45 & $0.02-2.02$ & & 1.06 & $0.02-38$ & 0.03 \\
Activated eosinophils & 0.195 & $0.03-1.34$ & & 1.22 & $0.69-28$ & 0.0017 \\
\hline
\end{tabular}

All figures are ratios reflecting T56/T0 data for each parameter.

†Mann-Whitney test for non-parametric data.

Total numbers of macrophages were reduced within two weeks of treatment but then rose again over the subsequent six week period, whereas the population of inductive RFD1+ cells showed a progressive fall over the eight week study period (fig 3C).

It therefore appears that the major FP induced improvement in lung function occurs during the first two weeks of treatment while the FP induced effects on immunological parameters continued to occur throughout the eight week period of the study without further significant improvement in tests of lung function.

\section{Discussion}

This paper reports for the first time the effects of inhaled fluticasone propionate on both immunopathological and physiological parameters of asthma over time in a placebo controlled study. Such a design reveals temporal relationships of the disease modulating effects of FP on two fronts.

Inhaled corticosteroids are the first line therapy for most patients with asthma. ${ }^{4633}$ Previous studies have shown how such therapy improves lung function, ${ }^{34}$ while others have shown reduction of the bronchial inflammation characteristic of this condition. ${ }^{736}$ Previous immunological investigations, however, have either been performed after a single period of treatment $\mathrm{t}^{8-10}$ and/or have not included a parallel placebo group. ${ }^{20}{ }^{37}$

The relationships between functional and immunological dysregulation in asthma remain unclear. Documentation of the effects of FP over a short term (two weeks) and a longer term (eight weeks) on the same group of subjects has shown the relative impact of treatment on both physiological and immunological parameters over time. The current results show, firstly, that improvement in physiological parameters occurs within two weeks of treatment. This result is consistent with previous studies. ${ }^{2635}$ By repeating such investigations on the same patients after eight weeks it is confirmed that no further significant improvement occurs beyond this two week period. Reduced bronchial hyperreactivity (BHR) to histamine was seen over the eight week period as previously observed, ${ }^{35}$ but comparison with the parallel placebo group showed this change not to be significant statistically.

The present results confirm further that inhaled corticosteroids reduce the numbers of inflammatory cells in the asthmatic bronchial wall. ${ }^{7810}$ In particular, the numbers of primed $\mathrm{T}$ cells and eosinophils are reduced after two weeks of treatment, confirming the antiinflammatory effects of FP reported by others. $^{37}$ However, study of the effects of continuing treatment at eight weeks shows that this effect on the immunopathology continues progressively over this extended period. As 
there is no significant further improvement in lung function beyond two weeks, these results support the suggestion that, while FP reverses both physiological and immunological abnormalities, these may be parallel but not interrelated effects. Such an observation would support previous suggestions that the dysregulation of both function and immunoregulation in asthmatic subjects does not necessarily represent a cause and effect relationship. ${ }^{19} 3839$

Of particular interest is the observation that reduction in the numbers of "activated" eosinophils in the tissues is most dramatic over the extended eight week period of FP treatment. Several studies have focused on the significance of eosinophil activation to the airway wall inflammation in asthma ${ }^{231516}$ and the consequent damage to the epithelium of the airways. Development of airways hyperresponsiveness has been attributed to the degranulation of these cells. ${ }^{318}$ Our results suggest that reduction in the eosinophil population may be consequential to the effect of FP on reducing the numbers of primed $\mathrm{T}$ lymphocytes in the mucosa. Such a possibility would fit with the knowledge that $\mathrm{T}$ cell derived cytokines are responsible for eosinophil activation and accumulation. ${ }^{40}$ It is thus tempting to speculate that the corticosteroid treatment acts by downregulating induction of immune reactivity, thus leading to reduced $T$ cell activation and subsequent eosinophil activation.

Comparison with placebo treated patients, however, failed to reveal FP dependent effects on the macrophage populations which were found to be variable in both groups of subjects. Thus the imbalance between suppressive and inductive macrophages, reported previously as characteristic of asthma, ${ }^{194}$ was not affected consistently by FP treatment. However, FP significantly reduced the overall inflammatory process in the bronchial wall of asthmatics in a progressive fashion over the eight week study period.

The temporal relationships between the antiinflammatory effects and the FP induced changes to functional parameters show that the well recognised clinical improvement seen over a two week period following FP treatment is associated with, but not dependent on, the antiinflammatory effect of the compound. More sustained treatment is required to impart its full impact on the inflammatory process associated with this condition, as even after eight weeks of FP treatment the numbers of $\mathrm{T}$ cells, macrophages, and eosinophils in the bronchial wall are not reduced to normal levels previously reported. ${ }^{42}$ This observation confirms the work of others who have shown that treatment periods extending to years also fail to "normalise" fully the cell populations of the mucosa. ${ }^{79}$

This work was supported by Glaxo/Wellcome UK. Colm T Leonard and Vincent J Tormey are supported by British Council Chevening Fellowships.

The authors acknowledge the excellent technical assistance of Ms Shelley J Poulter, the co-operation of the patients at the James Connolly Memorial Hospital, Dublin and the support of the Eastern Health Board, Dublin.

1 Nadel JA. Inflammation and asthma. $\mathcal{F}$ Allergy Clin Immunol 1984;73:651-3.
2 Azzawi M, Bradley B, Jeffery PK, et al. Identification of activated $\mathrm{T}$ lymphocytes and eosinophils in bronchial biopsies in stable atopic asthma. Am Rev Respir Dis 1990;42:1407-13.

3 Bousquet J, Chanez P, Lacoste JY. Eosinophilic inflammation in asthma. N Engl f Med 1990;323:1033-9.

4 Barnes PJ. Inhaled glucocorticoids for asthma. N Engl F Med 1995;332:868-75.

5 Laitinen LA, Laitinen A, and Haahtela T. A comparative study of the effects of an inhaled corticosteroid, budesonide, and of a $\beta_{2}$ agonist, terbutaline, on airway inflammation in newly diagnosed asthma: a randomised, doubleblind, parallel group, controlled trial. F Allergy Clin Immunol 1992; 90:32-42.

6 Haahtela T, Jarvinen $M$, Kava T, et al. Comparison of a $\beta_{2}$ agonist, terbutaline, with an inhaled corticosteroid, budesonide, in newly detected asthma. N Engl f Med 1991; 325:388-92.

7 Jeffery PK, Godfrey RW, Adelroth E, et al. Effects of treatment on airway inflammation and thickening of basement membrane reticular collagen in asthma: a quantitative light and electron microscopic study. Am Rev Respir Dis 1992;145:890-9.

8 Burke CM, Power CK, Norris A, et al. Lung function and immunopathological changes after inhaled corticosteroid therapy in asthma. Eur Respir F 1992;5:73-9.

9 Trigg CJ, Manolitsas D, Wang JH, et al. Placebo-controlled immunopathologic study of four months of inhaled corticosteroid in asthma. Am f Respir Crit Care Med 1994; 150:17-22.

10 Lundgren R, Soderberg M, Horstedt P, et al. Morphological studies of bronchial mucosal biopsies from asthmatics before and after ten years of treatment with inhaled steroids. Eur Respir f 1988;1:883-9.

11 American Thoracic Society. Guidelines for the diagnosis and treatment of patients with chronic obstructive pulmoand treatment of patients with chronic obstructive pulmonary disease (COPD

12 British Thoracic Society. British guidelines on asthma management: 1995 review and position statement. Thorax 1997;52:S1-21

13 Sterk PJ, Fabbri LM, Quanjer PH, et al. Airway responsiveness. Standardised challenge testing with pharmacological, physical and sensitizing stimuli in adults. Eur Respir 7 1993; 6(Suppl 16):53-83.

14 Jeffery PK, Wardlaw AJ, Nelson FC, et al. Bronchial biopsies in asthma, an ultrastructural, quantitative study and correlation with hyperreactivity. Am Rev Respir Dis 1989;140: 1745-53.

15 Sont JK, van Krieken JH, Evertse CE, et al. Relationship between the inflammatory infiltrate in bronchial biopsy specimens and clinical severity of asthma in patients treated with inhaled steroids. Thorax 1996;51:496-502.

16 Bentley AM, Menz G, Storz C, et al. Identification of T ymphocytes, macrophages, and activated eosinophils in the bronchial mucosa in intrinsic asthma. Relationship to symptoms and bronchial responsiveness. Am Rev Respir Dis 1992;146:500-6.

17 Robinson DS, Bentley AM, Hartnell A, et al. Activated memory $\mathrm{T}$ cells in bronchoalveolar lavage fluid from patients with atopic asthma: relation to asthma symptoms, lung function, and responsiveness. Thorax 1993;48:26-32.

18 Bradley BL, Azzawi M, Jacobsen M, et al. Eosinophils, T lymphocytes, mast cells, neutrophils, and macrophages in bronchial biopsy specimens from atopic subjects with asthma: comparison with biopsy specimens from atopic subjects without asthma and normal control subjects and
relationship to bronchial hyperresponsiveness. F Allergy Clin Immunol 1991;88:661-74.

19 Poulter LW, Janossy G, Power C, et al. Immunological/ physiological relationships in asthma: "potential regulation physiological relationships in asthma: "potential regulati

20 Juniper EF, Kline PA, Vanzieleghem MA, et al. Effect of long-term treatment with an inhaled corticosteroid (budesonide) on airway hyperresponsiveness and clinical asthma in non-steroid-dependent asthmatics. Am Rev Respir Dis 1990;142:832-6.

1 Barnes PJ, Pederson S. Efficacy and safety of inhaled corticosteroids in asthma. Am Rev Respir Dis 1993;148:S1-26.

22 Phillipps GH. Structure-activity relationships of topically active steroids: the selection of fluticasone propionate. Respir Med 1990;84:S19-23.

23 Harding SM. The human pharmacology of fluticasone propionate. Respir Med 1990;84:S25-9.

24 Hoekstra MO, Grol MH, Bouman K, et al. Fluticasone propionate in children with moderate asthma. Am f Respir Crit Care Med 1996;154:1039-44.

25 Fabbri L, Burge PS, Croonenborogh L, et al. Comparison of fluticasone propionate with beclomethasone in moderate to severe asthma treated for one year. Thorax 1993;48:81723

26 Noonan M, Chervinsky P, Busse WW, et al. Fluticasone propionate reduces oral predisolone use while it improves asthma control and quality of life. Am f Respir Crit Care Med 1995;152:1467-73.

27 Djukanovic R, Wilson JW, Lai CKW, et al. The safety aspects of fibreoptic bronchoscopy, bronchoalveolar lavage and bronchial biopsies in asthma. Am Rev Respir Dis 1991; 143:772-7.

28 Workshop Summary and Guidelines. Investigative use of bronchoscopy, lavage and bronchial biopsies in asthma and other airway diseases. Eur Respir f 1992;5:115-21.

29 Poulter LW, Power C, Burke C. The relationship between Poulter LW, Power C, Burke C. The relationship between
bronchial immunopathology and hyperresponsiveness in asthma. Eur Respir f 1990;3:792. 
30 Janossy G, Bofill M, Poulter LW. Two colour immunofluorescence analysis of the lymphoid system with monoclonal antibodies. In: Polak J, van Noorden S, eds. Immunocyto. Bristol: J Wright \& Sons, 1986:438.

31 Poulter LW, Norris A, Power C, et al. T cell dominated inflammatory reactions in the bronchioles of asymptomatic asthmatics are also present in the nasal mucosa. Postgrad Med F 1991;67:747-53.

32 Faul JL, Tormey VJ, Leonard C, et al. Lung immunopathology in cases of sudden asthma death. Eur Respir 7 1997;10 301-7.

33 Reed CE. Aerosol steroids as primary treatment of mild asthma. N Engl F Med 1991;325:425-6.

34 Barnes PJ. Effects of corticosteroids on airway hyperresponsiveness. Am Rev Respir Dis 1990;141:S70-6.

35 Vathenen AS, Knox AJ, Wisniewski A, et al. Time course of change in bronchial reactivity with an inhaled corticosteroid in asthma. Am Rev Respir Dis 1991;143:1317-21.

36 Djukanovic R, Wilson JW, Britten KM, et al. Effect of an inhaled corticosteroid on airway inflammation and symptoms in asthma. Am Rev Respir Dis 1992;145:669-74.
37 Booth $\mathrm{H}$, Richmond I, Ward C, et al. Effect of high dose inhaled fluticasone propionate on airway inflammation in asthma. Am F Respir Crit Care Med 1995;152:45-52.

38 Chapman ID, Foster A, Morley J. The relationship between 政 Clin Exp Allergy 1993;23:168-71.

39 Poulter LW, Burke C. Bronchial hyperreactivity in the presence and absence of inflammation. In: Kummar F, ed. Asthma immunopathology. New York: Springer-Verlag, 1995: 17-32.

40 Kay AB, Barata L, Meng Q, et al. Eosinophils and eosinophil-associated cytokines in allergic inflammation. Int Arch Allergy 1997;113:196-9.

41 Hutter C, Poulter LW.The balance of macrophage subsets may be customised at mucosal surfaces. FEMS Microbiol Immunol 1992;105:309-16.

42 Power CK, Burke C, Sreenan S, et al. T cell and macrophage subsets in the bronchial wall of clinically healthy subjects. Eur Respir F 1994;7:437-41. 